\title{
MODEL FOR ORE DEPOSITS SELECTION BY USING THE FUZZY TOPSIS METHOD
}

\author{
G. Popović1 ${ }^{1}$ D. Stanujkić², D. Karabašević1 1 Z. Štirbanović ${ }^{2}$ \\ 1 University Business Academy in Novi Sad, Faculty of Applied Management, Belgrade, Serbia \\ 2University in Belgrade, Technical Faculty, Bor, Serbia
}

(Received: May 8, 2020; Accepted: June 17, 2020)

\begin{abstract}
Decision-makers are often being faced with imprecise and ambiguous data. In such circumstances, the use of extended Multiple-Criteria Decision-Making (MCDM) method is more appropriate than the use of other classic decision-making techniques. This paper develops an evaluation model based on the Technique for Order Performance by Similarity to Ideal Solution (TOPSIS) to help the selection of the appropriate ore deposit for exploitation in a fuzzy environment. The applicability of the proposed model is demonstrated with a real case study involving four alternative ore deposits, seven evaluation criteria, and 3 decision-makers.
\end{abstract}

Key words: ore deposit selection, fuzzy TOPSIS, MCDM.

\section{Introduction}

Many authors have discussed models which are helpful for making decisions under unpredictable conditions. The prevalent approach among numerous others is multi-criteria decision making (MCDM) or multicriteria decision analysis (MCDA). This approach, which enables better management decisions must account for the variations in stake-holders preferences for criteria, and conflicting interests and values. At present, which is very complex and changeable, it becomes more difficult for decision-makers to identify appropriate alternative which maximizes all decision criteria [1].

Duckstein and Opricovic said that MCDM might be considered as a complex and dynamic process, including one managerial level and one engineering level [2]. The managerial level includes defining goals and selecting optimal alternative while engineering level defines alternatives and indicates the consequences of selecting any one of them. Belton and Stewart define MCDM as „an umbrella term to describe a collection of formal approaches which seek to take explicit account of multiple criteria in helping individuals or groups explore decisions that matter" [3].

MCDM methods have been classified in many different ways. The best-known classification is based on the number of alternatives that are under assessment and it includes the multi-attribute decision making (MADM) and multi-objective decision making (MODM). MADM methods are intended for election of discrete alternatives. MODM methods are more appropriate for multi-objective planning problems when there is the problem of simultaneous maximization or minimization of several objectives subject to a set of constraints [4-7].

Significant attention has been focused on applying of MCDM in resolving decision problems in the field of natural resources management over the past two decades. There are a number of papers about the application of these methods in the field of renewable resources and sustainable development. Comprehensive preview is given in the Mendoza and Martins [7]. But what about the use of MCDM methods in making decisions in mining?

Mining activities involve a particular level of risk that is not encountered in most other industries [8], and they include: geotechnical, mechanical, natural, and economical activities. Engineers should make a significant number of decisions which would reduce or eliminate these risks. Suitable aid in making the decisions in the field of mining could be the MCDM methods. These methods were often used for the selection of the mining method that is convenient for the particular ore deposit. For example, Alpay and Yavuz

\#Corresponding author: gabrijela.popovic@mef.edu.rs

doi: 10.5937/JMMA2001059P 
considered a decision support system for underground mining method selection [9]. The authors also tried to discover the optimum mining method by using the fuzzy analytic hierarchy process (AHP) [10-11]. Samimi Namin et al. proposed a new model for mining method selection based on the fuzzy decision making [12]. In their paper, Bogdanovic et al. applied the combination of the AHP and PROMETHEE methods for mining method selection [13], while Popović et al. proposed the use of the PIPRECIA-E method for the same purpose [14]. Besides the mining method selection, the authors have used the MCDM methods for the facilitation of the decision making directed to the other areas of mining. Azimi et al. ranked strategies of the mining sector through AHP and TOPSIS in a SWOT framework [15]. Kluge and Malan analyzed the application of the AHP method in complex mining engineering design problems [16]. Additionally, the authors have proposed the application of the MCDM methods for resolving the problems connected to the grinding circuit design selection [17-18] and for reconnaissance of minerals [19].

Choosing the right ore deposit for exploitation is also one of the risks with which mining engineers are faced. MCDM methods could be useful in the preliminary analysis for the selection of adequate ore deposit. In this paper the fuzzy TOPSIS method was used in order to select adequate ore deposit for exploitation. TOPSIS is widely applied in solving decision-making problems and risk analysis. Comprehensive preview is given in Jiang et al. [20]. Wang et al. used TOPSIS in fuzzy environment for the evaluation of initial training aircraft, and Mahmoodzadeh et al. assessed the projects by using fuzzy AHP and TOPSIS technique [21]. TOPSIS is also used for performance evaluation of Turkish cement firms [22], for bridge risk assessment [23] and for TQM consultant selection in SME's [24]. In mining, fuzzy TOPSIS is often used for equipment selection [25], for planning the mine reclamation [26], and shaft location selection [27]. Besides, the authors have proposed the various extensions of the TOPSIS method [28-30].

The main objective of this paper is to propose a systematic evaluation approach to help mining engineers in their preliminary analysis and selection of an ore deposit under fuzzy multi-criteria environment. Also, this paper is focused on emphasizing the applicability of the proposed approach. Evaluation within the ore deposit selection process is performed from the perspectives of mining engineers. This study utilizes the linguistic variables to determine the weights of criteria and TOPSIS method extended with triangular fuzzy numbers to obtain the performance ratings of the feasible alternatives [31]. This approach is proposed for the following reasons: (a) TOPSIS method is intelligible and logical; (b) the calculation procedure is unambiguous; (c) the approach enables the inquiry of the most suitable alternative regarding each criterion illustrated in an elemental mathematical form; and (d) the criteria weights are integrated into the process of evaluation [31-34].

The paper is organized as follows: section 2 briefly introduces the fuzzy set theory; alternative ore deposits and criteria are shown in section 3; section 4 contains proposed model; in section 5 numerical example is illustrated; and section 6 contains the conclusion.

\section{Fuzzy set theory}

The classical MCDM methods are based on the use of the classical set theory, where an element belongs or does not belong to the set.

Let $A$ be a classical set of objects, called the universe, whose generic elements are denoted by $x$. The belonging to a set $A$ can be represented by membership functions $\mu_{A}$ which have the following form [35]:

$\mu_{A}(x)=\left\{\begin{array}{ll}1 & x \in A, \\ 0 & x \notin A .\end{array}\right\}$

Unfortunately, many real-world decision-making problems are often related to the impact of uncertainty, which cannot be easily expressed using the classical sets.

Zadeh introduced the Fuzzy set theory in 1965, which permitted partial membership in a set [36]. This enabled the use of the other types of numbers such as triangular, trapezoidal, and bell-shaped numbers, and not only the crisp numbers. Additionally, as an extension of the fuzzy sets, the computation with words that implies a technique for the interpretation of the natural language requirements was introduced.

\subsection{The triangular fuzzy numbers}

Triangular fuzzy number $\tilde{A}$ (Figure 1) can fully be characterized by a triple of real numbers $(I, \mathrm{~m}, \mathrm{u})$ where parameters $\mathrm{I}, \mathrm{m}$, and $\mathrm{u}$ indicate the smallest possible value, the most promising value, and the largest possible value that describe a fuzzy event $[22,35]$. The 
membership function of the fuzzy number $\tilde{A}$ is defined as:

$\mu_{A}=\left\{\begin{array}{cc}0 & x<1 \\ (x-I) /(m-l) & 1 \leq x \leq m \\ (u-x) /(u-m) & 1 \leq x \leq u \\ 0 & x>u\end{array}\right.$

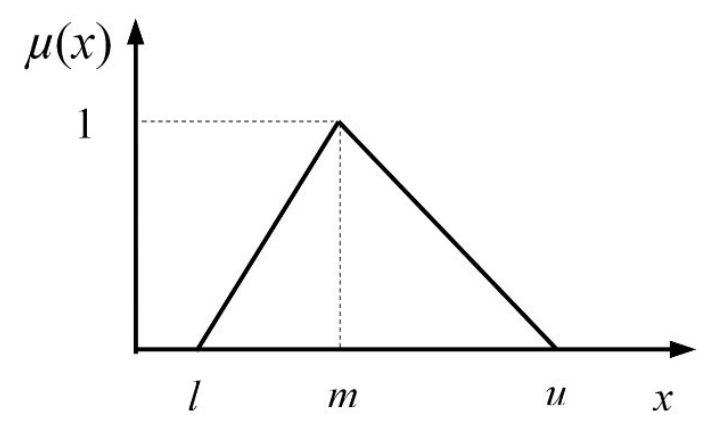

Figure 1 Triangular fuzzy number [37]

Let $\tilde{A}$ and $\tilde{B}$ be two triangular fuzzy numbers, parameterized by the triplet $\left(\mathrm{l}_{1}, \mathrm{~m}_{1}, \mathrm{u}_{1}\right)$ and $\left(\mathrm{I}_{2}, \mathrm{~m}_{2}, \mathrm{u}_{2}\right)$ respectively, then the operational laws these two triangular fuzzy numbers are as follows [31]:

$\tilde{\mathrm{A}}(+) \tilde{B}=\left(\mathrm{l}_{1}+\mathrm{l}_{2}, \mathrm{~m}_{1}+\mathrm{m}_{2}, \mathrm{u}_{1}+\mathrm{u}_{2}\right)$

$\tilde{A}(-) \tilde{B}=\left(l_{1}-u_{2}, m_{1}-m_{2}, u_{1}+l_{2}\right)$

$\tilde{A}(x) \tilde{B}=\left(\left.l_{1}\right|_{2}, m_{1} m_{2}, u_{1} u_{2}\right)$

$\tilde{\mathrm{A}}(\div) \tilde{\mathrm{B}}=\left(\frac{l_{1}}{\mathrm{u}_{2}}, \frac{\mathrm{m}_{1}}{\mathrm{~m}_{2}}, \frac{\mathrm{u}_{1}}{\mathrm{l}_{2}}\right)$

$\mathrm{k}(\mathrm{x}) \tilde{\mathrm{A}}=\left(\mathrm{kl}_{1}, \mathrm{~km}_{1}, \mathrm{ku}_{1}\right)$

$(\tilde{\mathrm{A}})^{-1}=\left(\frac{1}{\mathrm{u}_{1}}, \frac{1}{\mathrm{~m}_{1}}, \frac{1}{\mathrm{l}_{1}}\right)$

According to the vertex method, the distance between fuzzy number $\tilde{A}$ and $\tilde{B}$ is calculated as [37]:

$d_{E}(\tilde{A}, \tilde{B})=\sqrt{\frac{1}{3}}\left[\left(I_{1}-l_{2}\right)^{2}+\left(m_{1}+m_{2}\right)^{2}+\left(u_{1}-u_{2}\right)^{2}\right]$

\subsection{Linguistic variable}

Series of papers by Zadeh [38-40] introduced the concept of linguistic variables. According to Zadeh, the linguistic variables are defined as variables whose values are words or sentences in a natural or artificial language.

The concept of linguistic variable is very suitable for dealing with many real-world problems that are usually complex, slightly defined and related to uncertainties. The exclusive use of crisp numbers to represent the performance ratings of alternative and/or criteria weights when solving complex real-world problems requires some kind of averaging. In contrast, the use of linguistic variables, which are represented with corresponding fuzzy numbers (Figure 2), in such case is more appropriate.

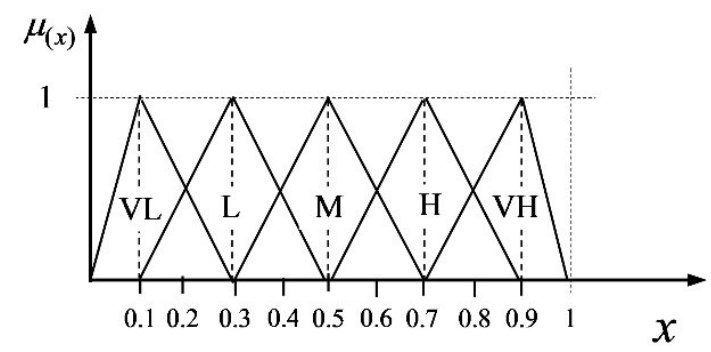

Figure 2 The membership functions of a linguistic variables

In the literature, numerous studies consider the use of numerous linguistic scales. For purposes of this paper we propose the application of linguistic scales proposed by Wang and Chang [31] and Wang and Chang [41], which are shown in Table 1 and 2.

Table 1 Linguistic scales for the weight of criteria

\begin{tabular}{cc}
\hline Linguistic variable & $\begin{array}{c}\text { Corresponding triangular } \\
\text { fuzzy number }\end{array}$ \\
\hline Very low $(\mathrm{VL})$ & $(0,0.1,0.3)$ \\
Low $(\mathrm{L})$ & $(0.1,0.3,0.5)$ \\
Medium $(\mathrm{M})$ & $(0.3,0.5,0.7)$ \\
High $(\mathrm{H})$ & $(0.5,0.7,0.9)$ \\
Very high $(\mathrm{VH})$ & $(0.7,0.9,1.0)$ \\
\hline
\end{tabular}

Table 2 Linguistic scales for the ratings of alternatives

\begin{tabular}{cc}
\hline Linguistic variable & $\begin{array}{c}\text { Corresponding triangular } \\
\text { fuzzy number }\end{array}$ \\
\hline Very poor (VP) & $(0,1,3)$ \\
Poor (P) & $(1,3,5)$ \\
Medium (F) & $(3,5,7)$ \\
High (G) & $(5,7,9)$ \\
Very high (VG) & $(7,9,10)$ \\
\hline
\end{tabular}

\section{Ore deposits in Central Serbia}

Making a decision about the exploitation of some 
ore deposit is connected to a certain amount of risk. Decision-makers use appropriate methodologies which help them to avoid or reduce the risks and make the right decision. In this paper, we propose an approach for ore deposit selection based on the fuzzy TOPSIS method. This approach is helpful in the preliminary ranking of ore deposits.

Fuzzy TOPSIS is applied to the ore deposits selection in Central Serbia. The main metal in these deposits is copper, including some amounts of silver and gold. Question is: Which of these deposits should have priority in exploitation? The criteria, under which multi-criteria analysis is performed, were derived through investigation the literature [42-44] and consultation with three experts. In this case, the effect of exploitation on the environment, as well as the economic aspect of exploitation were not included. The criteria are as follows:

- $\mathrm{C}_{1}$ - Copper content in ore (\%). The ore deposit with higher copper content has the advantage.

- $\mathrm{C}_{2}$ - Silver content in ore $(\mathrm{g} / \mathrm{t})$. The ore deposit with higher silver content has the advantage.

- $\mathrm{C}_{3}$ - Gold content in ore $(\mathrm{g} / \mathrm{t})$. The ore deposit with higher gold content has the advantage.

- $\mathrm{C}_{4}$ - Examination of the balance reserves. Explored masses of the minerals in the deposit or part of the deposit which can be rationally and economically used with present techniques and technologies of exploitation and processing. Better examined deposits have the advantage.

- $\mathrm{C}_{5}$ - Location. Geospatial position of the ore deposit and transport infrastructure. The ore deposit which has a better position and which is closer to the major highways is desirable.

- $\mathrm{C}_{6}-$ Size of ore deposit. The bigger ore deposit is more desirable for exploitation.

- $\mathrm{C}_{7}$ - Mining-geological conditions of exploitation. Mining-geological conditions include many characteristics of the ore deposit, such as the shape of the ore body, depth, contact with the surrounding rocks and others that are very significant for selection of exploitation method and have an influence on the exploitation costs.

The following four ore deposits in Central Serbia were compared:

- $A_{1}$ - Južni revir -Majdanpek district. Ore deposit called Južni revir is the biggest in this area. Ore reserves of this deposit amount near $405 \times 10^{6}$ dry ore, with the average content of copper of $0.335 \%$, gold $0.188 \mathrm{~g} / \mathrm{t}$, and silver $1.26 \mathrm{~g} / \mathrm{t}$. The total amount of metal in this geological reserve of ore is $1,356,670 \mathrm{t}$ of copper, $76,256 \mathrm{~kg}$ of gold, and $510,883 \mathrm{~kg}$ of silver.

- $\mathrm{A}_{2}$ - Severni revir - Majdanpek district. The Severni revir is the second ore deposit according to size, which is located near Majdanpek. There are a few smaller ore bodies in this area which economic significance is questionable from the perspective of longer exploitation. Ore reserves of Severni revir amount near $220 \times 10^{6} \mathrm{t}$, with $0.306 \%$ of copper, $0.263 \mathrm{~g} / \mathrm{t}$ of gold, and $2.001 \mathrm{~g} / \mathrm{t}$ of silver, with total amount of copper $673,880 \mathrm{t}, 57,878 \mathrm{~kg}$ gold, and 440,537 silver [45].

- $\mathrm{A}_{3}$ - Aldinac - Knjaževac district. Aldinac is located in the Knjaževac district, which is in Central Serbia, near the border with Bulgaria. In the period from 1956 to 1958, RTB Bor was doing research in area of Aldinac and found significant amount of gold, silver, and bismuth. Content of certain metals in this area are: copper 4\%, gold $24 \mathrm{~g} / \mathrm{t}$, silver $120 \mathrm{~g} / \mathrm{t}$, etc [46].

- $\mathrm{A}_{4}$ - Markov kamen - Boljevac district. This ore deposit is located nearl the town of Boljevac. Chemical analysis shows low content of copper in these reserves, while the content of silver is high and it goes from $16.1 \mathrm{~g} / \mathrm{t}$ to $32 \mathrm{~g} / \mathrm{t}$, even $144 \mathrm{~g} / \mathrm{t}$ in some parts of the deposit. Maximum content of gold is about $0.2 \mathrm{~g} / \mathrm{t}[47]$.

\section{Proposed method}

A systematic approach pointed to the development of the extended TOPSIS method which will be used for ore deposit selection problem in fuzzy environment is proposed in this section. The basic steps of the proposed methodology consist of the following items:

- Step 1 - Determine the objectives, available alternatives and the evaluation criteria.

- Step 2 - Determine the weights of evaluation criteria.

In MCDM, the weights of criteria are very significant. As a result, a number of different approaches is proposed in literature, such as pairwise comparisons taken from the AHP method, Entropy method and so on. To determine a more realistic weight of criteria it is often necessary to examine the opinion of several experts, from a given field. In such cases the use of linguistic variables can be very appropriate.

Several linguistic scales with various numbers of elements were proposed in literature. The use of 
different fuzzy distribution forms for quantification of linguistic variables, such as trapezoidal, triangular, and interval form were studied as well. In this approach, the use of linguistic scale with five variables is proposed, shown in Table 1, which is adopted from Wang and Chang $[31,41]$.

For a decision-making problem which involves decision-makers, where the performance ratings are expressed using the triangular fuzzy numbers, the fuzzy weights of evaluation criteria can be calculated using the following formula:

$\widetilde{\mathrm{W}}_{\mathrm{j}}=\frac{1}{\mathrm{~K}}\left(\widetilde{\mathrm{W}}_{\mathrm{j}}^{1}+\widetilde{\mathrm{W}}_{\mathrm{j}}^{2}+\ldots+\widetilde{\mathrm{W}}_{\mathrm{j}}^{\mathrm{K}}\right)$

where $\widetilde{w}_{j}$ represents fuzzy weight of $j$-th criterion, $\widetilde{w}_{j}^{K}$ represent the weight of $j$-th criterion assessed by $k$-th decision-makers, expressed using triangular fuzzy numbers; $\mathrm{j}=1,2, \ldots, \mathrm{n} ; \mathrm{n}$ is number of criteria; $\mathrm{k}=1,2, \ldots, \mathrm{K}$.

- Step 3 - Determine the performance ratings of alternatives and construct the fuzzy decision matrix.

An ore deposit selection problem, which involves $\mathrm{K}$ decision makers, can be expressed in the matrix as follows:

$\widetilde{D}^{k}=\left[\tilde{x}_{i j}^{k}\right]_{m \times n}$

where $\widetilde{D}^{k}$ is fuzzy decision matrix formed by k-th decision maker/expert; $\tilde{x}_{i j}^{k}$ fuzzy performance rating, expressed in the form of linguistic variables, of i-th alternative to the $\mathrm{j}$-th criterion given by $\mathrm{k}$-th decision maker; $i=1,2, \ldots, m ; m$ is number of alternatives; $j=1,2, \ldots, n ; n$ is number of criteria; $k=1,2, \ldots, K$.

The values from Table 2 are used for alternative performance according to the considered criteria.

As a result of previous action, we have $k$ decision matrix. Because of that it is necessary to form resulting decision matrix:

$\widetilde{\mathrm{D}}=\left[\tilde{\mathrm{X}}_{\mathrm{ij}}\right]$

where $\tilde{\mathrm{x}}_{\mathrm{ij}}$ represent the resulting performance rating of $\mathrm{i}$ th alternative to the $\mathrm{j}$-th criterion, and its value is determined by follows the equation:

$\tilde{x}_{i j}=\frac{1}{K}\left(\tilde{x}_{i j}^{1}+\tilde{x}_{i j}^{2}+\ldots+\tilde{x}_{i j}^{K}\right)$ where $\tilde{x}_{i j}$ is a fuzzy performance rating of $i$-th alternative to the j-th criterion.

During forming the resulting fuzzy decision matrix, shown by equation (13), the linguistic variables are transformed in a corresponding triangular fuzzy numbers also.

- Step 4 - Normalize the fuzzy decision matrix.

The next step in the proposed methodology is to normalize fuzzy performance ratings and construct a normalized fuzzy decision matrix $\widetilde{R}$, as follows:

$\widetilde{R}=\left[\tilde{r}_{i j}\right]$

where $\tilde{r}_{i j}$ is normalized fuzzy performance rating of $i$-th alternative to the j-th criterion.

Ordinary TOPSIS is based on the use of Vector normalization method. Due of its complexity, in many extensions of TOPSIS method Vector normalization method is substituted with significantly easier linear scale transformation, and normalized fuzzy performance ratings determine by using the following equation:

$\tilde{r}_{i j}=\left(\frac{a_{i j}}{c_{j}^{+}}, \frac{b_{i j}}{c_{j}^{+}}, \frac{c_{i j}}{c_{j}^{+}}\right)$

where

$c_{j}^{+}=\max _{i} c_{i j}$

- Step 5 - Construct weighted normalized fuzzy decision matrix.

Considering the different weight of each criterion, the next step in proposed methodology is forming of weighted normalized fuzzy decision matrix $\tilde{V}$. The weighted normalized fuzzy decision matrix $\tilde{V}$ can be expressed as follows:

$\tilde{V}=\left[\tilde{v}_{i j}\right]$

where

$\widetilde{\mathrm{V}}_{\mathrm{ij}}=\tilde{\mathrm{r}}_{\mathrm{ij}}(\mathrm{x}) \widetilde{\mathrm{w}}_{\mathrm{j}}$

- Step 6 - Determine the fuzzy positive ideal solution and fuzzy negative ideal solution.

Included in the ordinary TOPSIS, the positive ideal solution indicates the most preferable alternative $A^{+}$, and the negative ideal solution indicates the least 
preferable alternative $A^{-}$, which can be determined using the following equations:

$$
\begin{aligned}
A^{+} & =\left\{v_{1}^{+}, v_{2}^{+}, \ldots, v_{n}^{+}\right\}= \\
& =\left\{\left(\max _{i} \tilde{v}_{i j} \mid j \in \Omega^{+}\right),\left(\min _{i} \tilde{v}_{i j} \mid j \in \Omega^{-}\right)\right\} \\
A^{-} & =\left\{v_{1}^{-}, v_{2}^{-}, \ldots, v_{n}^{-}\right\}= \\
& =\left\{\left(\max _{i} \tilde{v}_{i j} \mid j \in \Omega^{+}\right),\left(\min _{i} \tilde{v}_{i j} \mid j \in \Omega^{-}\right)\right\}
\end{aligned}
$$

where $\Omega^{+}$and $\Omega^{-}$denote a set of benefit and cost type criteria, respectively.

In a number of TOPSIS extensions, different authors had different approaches for determining the ideal point. Some of them still use ideal and anti-ideal point, while some of them use fuzzy ideal and anti-ideal point with the following coordinates $\tilde{v}_{j}^{+}=(1,1,1)$ and $\tilde{v}_{j}^{-}=(0,0,0)$ when $j$ is benefit type criteria, or opposite $\tilde{v}_{j}^{+}=(0,0,0)$ and $\tilde{v}_{j}=(1,1,1)$, when $j$ is cost type criteria.

In the proposed approach the positive and negative ideal solution are sets of fuzzy numbers, as follows:

$A^{+}=\left\{\tilde{V}_{1}^{+}, \widetilde{V}_{2}^{+}, \ldots, \widetilde{V}_{n}^{+}\right\}$, and

$A^{-}=\left\{\tilde{V}_{1}, \tilde{V}_{2}, \ldots, \tilde{V}_{n}^{-}\right\}$

where $\tilde{v}_{j}^{+}$and $\tilde{v}_{j}^{-}$represent fuzzy number $\tilde{v}_{j}^{+}=\left(v_{j}^{l+}, v_{j}^{m+}, v_{j}^{u+}\right)$ and $\tilde{v}_{j}^{-}=\left(v_{j}^{l-}, v_{j}^{m-}, v_{j}^{u-}\right)$ which left, middle right borders are computing as follows:

$v_{j}^{l^{+}}= \begin{cases}\max _{i} v_{j}^{l} ; & j \in \Omega^{+} \\ \min _{i} v_{j}^{l} ; & j \in \Omega^{-}\end{cases}$

$v_{j}^{m+}= \begin{cases}\max _{i} v_{j}^{m} ; & j \in \Omega^{+} \\ \min _{i} v_{j}^{m} ; & j \in \Omega^{-}\end{cases}$

$v_{j}^{u+}= \begin{cases}\max _{i} v_{j}^{u} ; & j \in \Omega^{+} \\ \min _{i} v_{j}^{u} ; & j \in \Omega^{-}\end{cases}$

$v_{j}^{l-}= \begin{cases}\max _{i} v_{j}^{l} ; & j \in \Omega^{+} \\ \min _{i} v_{j}^{\prime} ; & j \in \Omega^{-}\end{cases}$

$v_{j}^{m-}= \begin{cases}\max _{i} v_{j}^{m} ; & j \in \Omega^{+} \\ \min _{i} v_{j}^{m} ; & j \in \Omega^{-}\end{cases}$

$v_{j}^{u-}= \begin{cases}\max _{i} v_{j}^{u} ; & j \in \Omega^{+} \\ \min _{i}^{u} v_{j}^{u} ; & j \in \Omega^{-}\end{cases}$

- Step 7 - Calculate the distances of each alternative from the ideal and the negative ideal

\section{solutions.}

The distance of each alternative from the fuzzy positive ideal $A^{+}$and fuzzy negative ideal $A^{-}$solutions can be calculated as:

$d_{i}^{+}=\sum_{j=1}^{n} d\left(v_{i j} v_{j}^{+}\right)$

and

$d_{i}=\sum_{j=1}^{n} d\left(v_{i j} v_{j}^{-}\right)$

where $d\left({ }^{*},{ }^{*}\right)$ is the distance measurement between two fuzzy numbers, and in proposed approach these distances are calculated using the equation (9).

- Step 8-Calculate the closeness coefficient.

After all, as in ordinary TOPSIS, closeness coefficient can be determine by using the equation:

$C_{i}=\frac{d_{i}^{-}}{d_{i}^{+}+d_{i}^{-}}$

Once the closeness coefficient is determined, the ranking order of all alternatives can be obtained.

\section{- Step 9-Rank the alternatives.}

A set of alternatives can now be ranked according to the descending order of $\mathrm{C}_{i}$, and the one with the maximum value of $C_{i}$ is the best.

\section{Numerical example}

A numerical example is illustrated for presenting the applicability of the fuzzy TOPSIS for ore deposits selection in Central Serbia. Four ore deposits $\left(A_{1}, A_{2}, A_{3}\right.$ and $\left.A_{4}\right)$ are evaluated by three experts against seven evaluating criteria $\left(\mathrm{C}_{1}, \mathrm{C}_{2}, \mathrm{C}_{3}, \ldots, \mathrm{C}_{7}\right)$, which are above mentioned. Table 3 shows the data on mentioned ore deposits according to different criteria.

In order to evaluate the ore deposits, a group of three experts is formed. At the beginning, each expert evaluates the selected evaluation criteria, using the linguistic variables from Table 1. Assigned linguistic variables and the weights of criteria, obtained by using equation (10) are shown in Table 4.

In the next step, experts evaluate the performance ratings of considered alternatives to the selected criteria, 
also using linguistic variables, but now from Table 2. and corresponding quantitative values are shown in Assigned linguistic variables for performance ratings Table 5.

Table 3 Input data

\begin{tabular}{cccccccc}
\hline & $\begin{array}{c}\text { Copper } \\
\text { content } \\
\%\end{array}$ & $\begin{array}{c}\text { Silver } \\
\text { content } \\
\text { g/t }\end{array}$ & $\begin{array}{c}\text { Gold } \\
\text { content } \\
\text { g/t }\end{array}$ & $\begin{array}{c}\text { Examination } \\
\text { of balance } \\
\text { reserves }\end{array}$ & Location & $\begin{array}{c}\text { Size of } \\
\text { the ore } \\
\text { deposit }\end{array}$ & $\begin{array}{c}\text { Mining-geological } \\
\text { conditions of } \\
\text { exploitation }\end{array}$ \\
\cline { 2 - 7 } & $\max$ & $\max$ & $\max$ & $\max$ & min & max & max \\
Južni revir & 0.335 & 1.260 & 0.188 & high & average & high & high \\
Severni revir & 0.306 & 2.001 & 0.263 & high & average & high & high \\
Aldinac & 4.000 & 120.000 & 24.000 & very low & low & very low & very low \\
Markov kamen & 0.100 & $16.1-144$ & 0.2000 & very low & low & very low & very low \\
\hline
\end{tabular}

Table 4 Weights of the criteria

\begin{tabular}{llcccc}
\hline \multicolumn{1}{c}{ Criteria } & $\mathrm{E}_{1}$ & $\mathrm{E}_{2}$ & $\mathrm{E}_{3}$ & $\mathrm{w}_{\mathrm{j}}$ \\
\hline $\mathrm{C}_{1}$ & Copper content & $\mathrm{VH}$ & $\mathrm{H}$ & $\mathrm{H}$ & {$[0.33,0.50,0.70]$} \\
$\mathrm{C}_{2}$ & Silver content & $\mathrm{M}$ & $\mathrm{H}$ & $\mathrm{M}$ & {$[0.37,0.57,0.77]$} \\
$\mathrm{C}_{3}$ & Gold content & $\mathrm{H}$ & $\mathrm{H}$ & $\mathrm{H}$ & {$[0.50,0.70,0.90]$} \\
$\mathrm{C}_{4}$ & Examination of balance reserves & $\mathrm{H}$ & $\mathrm{VH}$ & $\mathrm{VH}$ & {$[0.17,0.30,0.50]$} \\
$\mathrm{C}_{5}$ & Location & $\mathrm{L}$ & $\mathrm{M}$ & $\mathrm{L}$ & {$[0.17,0.37,0.57]$} \\
$\mathrm{C}_{6}$ & Size of the ore deposit & $\mathrm{H}$ & $\mathrm{H}$ & $\mathrm{VH}$ & {$[0.33,0.50,0.70]$} \\
$\mathrm{C}_{7}$ & Mining-geological conditions of exploitation & $\mathrm{VH}$ & $\mathrm{VH}$ & $\mathrm{H}$ & {$[0.17,0.30,0.50]$} \\
\hline
\end{tabular}

Table 5 Performance ratings of criteria

\begin{tabular}{|c|c|c|c|c|c|}
\hline Criteria & & $\mathrm{E}_{1}$ & $E_{2}$ & $E_{3}$ & $w_{j}$ \\
\hline \multirow{4}{*}{$C_{1}$} & $A_{1}$ & $P$ & $G$ & $P$ & {$[2.33,4.33,6.33]$} \\
\hline & $A_{2}$ & $\mathrm{P}$ & G & $P$ & {$[2.33,4.33,6.33]$} \\
\hline & $\mathrm{A}_{3}$ & VG & $P$ & VG & {$[5.00,7.00,8.33]$} \\
\hline & $\mathrm{A}_{4}$ & VG & $\mathrm{P}$ & VP & {$[2.67,4.33,6.00]$} \\
\hline \multirow{4}{*}{$\mathrm{C}_{2}$} & $A_{1}$ & $F$ & G & $\mathrm{F}$ & {$[3.67,5.67,7.67]$} \\
\hline & $\mathrm{A}_{2}$ & $\mathrm{~F}$ & G & $\mathrm{F}$ & {$[3.67,5.67,7.67]$} \\
\hline & $A_{3}$ & VG & $\mathrm{P}$ & VG & {$[5.00,7.00,8.33]$} \\
\hline & $\mathrm{A}_{4}$ & VG & $\mathrm{P}$ & VG & {$[5.00,7.00,8.33]$} \\
\hline \multirow{4}{*}{$\mathrm{C}_{3}$} & $A_{1}$ & $\mathrm{~F}$ & G & $P$ & {$[3.00,5.00,7.00]$} \\
\hline & $\mathrm{A}_{2}$ & $\mathrm{~F}$ & G & $P$ & {$[3.00,5.00,7.00]$} \\
\hline & $\mathrm{A}_{3}$ & VG & $P$ & VG & {$[5.00,7.00,8.33]$} \\
\hline & $\mathrm{A}_{4}$ & $\mathrm{~F}$ & $\mathrm{P}$ & $P$ & {$[1.67,3.67,5.67]$} \\
\hline \multirow{4}{*}{$\mathrm{C}_{4}$} & $A_{1}$ & VG & VG & VG & {$[7.00,9.00,10.00]$} \\
\hline & $\mathrm{A}_{2}$ & VG & VG & VG & {$[7.00,9.00,10.00]$} \\
\hline & $\mathrm{A}_{3}$ & VP & VP & $P$ & {$[0.33,1.67,3.67]$} \\
\hline & $\mathrm{A}_{4}$ & VP & VP & VG & {$[2.33,3.67,5.33]$} \\
\hline \multirow{4}{*}{$\mathrm{C}_{5}$} & $A_{1}$ & G & $\mathrm{F}$ & $\mathrm{F}$ & {$[3.67,5.67,7.67]$} \\
\hline & $\mathrm{A}_{2}$ & G & $\mathrm{F}$ & $\mathrm{F}$ & {$[3.67,5.67,7.67]$} \\
\hline & $A_{3}$ & $\mathrm{~F}$ & $\mathrm{P}$ & $\mathrm{F}$ & {$[2.33,4.33,6.33]$} \\
\hline & $\mathrm{A}_{4}$ & $\mathrm{~F}$ & $\mathrm{P}$ & $\mathrm{P}$ & {$[1.67,3.67,5.67]$} \\
\hline \multirow{4}{*}{$\mathrm{C}_{6}$} & $A_{1}$ & G & G & G & {$[5.00,7.00,9.00]$} \\
\hline & $\mathrm{A}_{2}$ & G & G & G & {$[5.00,7.00,9.00]$} \\
\hline & $\mathrm{A}_{3}$ & VP & $P$ & $P$ & {$[0.67,2.33,4.33]$} \\
\hline & $\mathrm{A}_{4}$ & VP & $\mathrm{P}$ & $\mathrm{P}$ & {$[0.67,2.33,4.33]$} \\
\hline \multirow{4}{*}{$\mathrm{C}_{7}$} & $A_{1}$ & $\mathrm{P}$ & VG & $P$ & {$[3.00,5.00,6.67]$} \\
\hline & $\mathrm{A}_{2}$ & $\mathrm{~F}$ & VG & $\mathrm{F}$ & {$[4.33,6.33,8.00]$} \\
\hline & $A_{3}$ & $\mathrm{~F}$ & VP & $\mathrm{F}$ & {$[2.00,3.67,5.67]$} \\
\hline & $\mathrm{A}_{4}$ & $\mathrm{~F}$ & VP & $\mathrm{F}$ & {$[2.00,3.67,5.67]$} \\
\hline
\end{tabular}


Based on the data shown in Table 5 , using the equation (13) a fuzzy decision matrix is formed, which is shown in Table 6a and 6b.

Table 6a Fuzzy decision matrix

\begin{tabular}{ccccc}
\hline & $\mathrm{C}_{1}$ & $\mathrm{C}_{2}$ & $\mathrm{C}_{3}$ & $\mathrm{C}_{4}$ \\
\hline $\mathrm{w}_{\mathrm{j}}$ & {$[0.33,0.50,0.70]$} & {$[0.37,0.57,0.77]$} & {$[0.50,0.70,0.90]$} & {$[0.17,0.30,0.50]$} \\
Opt. & $\min$ & $\min$ & $\min$ & $\min$ \\
$\mathrm{A}_{1}$ & {$[2.33,4.33,6.33]$} & {$[3.67,5.67,7.67]$} & {$[3.00,5.00,7.00]$} & {$[7.00,9.00,10.00]$} \\
$\mathrm{A}_{2}$ & {$[2.33,4.33,6.33]$} & {$[3.67,5.67,7.67]$} & {$[3.00,5.00,7.00]$} & {$[7.00,9.00,10.00]$} \\
$\mathrm{A}_{3}$ & {$[5.00,7.00,8.33]$} & {$[5.00,7.00,8.33]$} & {$[5.00,7.00,8.33]$} & {$[0.33,1.67,3.67]$} \\
$\mathrm{A}_{4}$ & {$[2.67,4.33,6.00]$} & {$[5.00,7.00,8.33]$} & {$[1.67,3.67,5.67]$} & {$[2.33,3.67,5.33]$} \\
\hline
\end{tabular}

Table 6b Fuzzy decision matrix (continued)

\begin{tabular}{cccc}
\hline & $\mathrm{C}_{5}$ & $\mathrm{C}_{6}$ & $\mathrm{C}_{7}$ \\
\hline $\mathrm{w}_{\mathrm{j}}$ & {$[0.17,0.37,0.57]$} & {$[0.33,0.50,0.70]$} & {$[0.17,0.30,0.50]$} \\
Opt. & $\max$ & $\max$ & $\max$ \\
$\mathrm{A}_{1}$ & {$[3.67,5.67,7.67]$} & {$[5.00,7.00,9.00]$} & {$[3.00,5.00,6.67]$} \\
$\mathrm{A}_{2}$ & {$[3.67,5.67,7.67]$} & {$[5.00,7.00,9.00]$} & {$[4.33,6.33,8.00]$} \\
$\mathrm{A}_{3}$ & {$[2.33,4.33,6.33]$} & {$[0.67,2.33,4.33]$} & {$[2.00,3.67,5.67]$} \\
$\mathrm{A}_{4}$ & {$[1.67,3.67,5.67]$} & {$[0.67,2.33,4.33]$} & {$[2.00,3.67,5.67]$} \\
\hline
\end{tabular}

After that, using the equations (14)-(16) a normalized fuzzy decision matrix are shown in Table 7a normalized fuzzy decision matrix is formed. The and $7 \mathrm{~b}$.

Table 7a Normalized fuzzy decision matrix

\begin{tabular}{ccccc}
\hline \multicolumn{1}{c}{$\mathrm{C}_{1}$} & $\mathrm{C}_{2}$ & $\mathrm{C}_{3}$ & $\mathrm{C}_{4}$ \\
\hline $\mathrm{A}_{1}$ & {$[0.28,0.52,0.76]$} & {$[0.44,0.68,0.92]$} & {$[0.36,0.60,0.84]$} & {$[0.70,0.90,1.00]$} \\
$\mathrm{A}_{2}$ & {$[0.28,0.52,0.76]$} & {$[0.44,0.68,0.92]$} & {$[0.36,0.60,0.84]$} & {$[0.70,0.90,1.00]$} \\
$A_{3}$ & {$[0.60,0.84,1.00]$} & {$[0.60,0.84,1.00]$} & {$[0.60,0.84,1.00]$} & {$[0.03,0.17,0.37]$} \\
$\mathrm{A}_{4}$ & {$[0.32,0.52,0.72]$} & {$[0.60,0.84,1.00]$} & {$[0.20,0.44,0.68]$} & {$[0.23,0.37,0.53]$} \\
\hline
\end{tabular}

Table $7 \mathrm{~b}$ Normalized fuzzy decision matrix (continued)

\begin{tabular}{cccc}
\hline & $\mathrm{C}_{5}$ & $\mathrm{C}_{6}$ & $\mathrm{C}_{7}$ \\
\hline $\mathrm{A}_{1}$ & {$[0.48,0.74,1.00]$} & {$[0.56,0.78,1.00]$} & {$[0.38,0.63,0.83]$} \\
$\mathrm{A}_{2}$ & {$[0.48,0.74,1.00]$} & {$[0.56,0.78,1.00]$} & {$[0.54,0.79,1.00]$} \\
$\mathrm{A}_{3}$ & {$[0.30,0.57,0.83]$} & {$[0.07,0.26,0.48]$} & {$[0.25,0.46,0.71]$} \\
$\mathrm{A}_{4}$ & {$[0.22,0.48,0.74]$} & {$[0.07,0.26,0.48]$} & {$[0.25,0.46,0.71]$} \\
\hline
\end{tabular}

In the next step by using the equations (17) and formed (Table 8a and 8b). (18), the weighted normalized fuzzy decision matrix is

Table 8a Weighted normalized fuzzy decision matrix

\begin{tabular}{ccccc}
\hline & $\mathrm{C}_{1}$ & $\mathrm{C}_{2}$ & $\mathrm{C}_{3}$ & $\mathrm{C}_{4}$ \\
\hline $\mathrm{A}_{1}$ & {$[0.09,0.26,0.53]$} & {$[0.16,0.39,0.71]$} & {$[0.18,0.42,0.76]$} & {$[0.12,0.27,0.50]$} \\
$\mathrm{A}_{2}$ & {$[0.09,0.26,0.53]$} & {$[0.16,0.39,0.71]$} & {$[0.18,0.42,0.76]$} & {$[0.12,0.27,0.50]$} \\
$\mathrm{A}_{3}$ & {$[0.20,0.42,0.70]$} & {$[0.22,0.48,0.77]$} & {$[0.30,0.59,0.90]$} & {$[0.01,0.05,0.18]$} \\
$\mathrm{A}_{4}$ & {$[0.11,0.26,0.50]$} & {$[0.22,0.48,0.77]$} & {$[0.10,0.31,0.61]$} & {$[0.04,0.11,0.27]$} \\
\hline
\end{tabular}


Table 8b Weighted normalized fuzzy decision matrix (continued)

\begin{tabular}{cccc}
\hline & $\mathrm{C}_{5}$ & $\mathrm{C}_{6}$ & $\mathrm{C}_{7}$ \\
\hline $\mathrm{A}_{1}$ & {$[0.08,0.27,0.57]$} & {$[0.19,0.39,0.70]$} & {$[0.06,0.19,0.42]$} \\
$\mathrm{A}_{2}$ & {$[0.08,0.27,0.57]$} & {$[0.19,0.39,0.70]$} & {$[0.09,0.24,0.50]$} \\
$\mathrm{A}_{3}$ & {$[0.05,0.21,0.47]$} & {$[0.02,0.13,0.34]$} & {$[0.04,0.14,0.35]$} \\
$\mathrm{A}_{4}$ & {$[0.04,0.18,0.42]$} & {$[0.02,0.13,0.34]$} & {$[0.04,0.14,0.35]$} \\
\hline
\end{tabular}

The best (ideal) $A_{j}^{+}$and the worst (negative ideal) $A_{j}^{-}$ performance rating, for every criterion are determined using the following equations (21)-(28), and these values are shown in Table $9 a$ and $9 b$.

Table 9a The ideal and anti-ideal performance ratings

\begin{tabular}{ccccc}
\hline & $\mathrm{C}_{1}$ & $\mathrm{C}_{2}$ & $\mathrm{C}_{3}$ & $\mathrm{C}_{4}$ \\
\hline $\mathrm{x}_{\mathrm{j}}^{+}$ & {$[0.20,0.42,0.70]$} & {$[0.22,0.48,0.77]$} & {$[0.30,0.59,0.90]$} & {$[0.12,0.27,0.50]$} \\
$\mathrm{x}_{\mathrm{j}}^{-}$ & {$[0.09,0.26,0.50]$} & {$[0.16,0.39,0.71]$} & {$[0.10,0.31,0.61]$} & {$[0.01,0.05,0.18]$} \\
\hline
\end{tabular}

Table $9 \mathrm{~b}$ The ideal and anti-ideal performance ratings (continued)

\begin{tabular}{cccc}
\hline & $\mathrm{C}_{5}$ & $\mathrm{C}_{6}$ & $\mathrm{C}_{7}$ \\
\hline $\mathrm{x}_{\mathrm{j}}^{+}$ & {$[0.08,0.27,0.57]$} & {$[0.19,0.39,0.70]$} & {$[0.09,0.24,0.50]$} \\
$\mathrm{x}_{\mathrm{j}}^{-}$ & {$[0.04,0.18,0.42]$} & {$[0.02,0.13,0.34]$} & {$[0.04,0.14,0.35]$} \\
\hline
\end{tabular}

Equations (9), (29), and (30), respectively derive the distance of each alternative ore deposit to the fuzzy positive ideal reference point and fuzzy negative reference point, as shown in Table 10 (columns I and II). Once the distance of ore deposit from FPIRP and FNIRP are determined, the closeness coefficient can be obtained with equation (31) and the rank of the ore deposits can be made. Table 10, column III and IV, shows closeness coefficient and rank of ore deposit.

Table 10 The closeness coefficient and rank of the ore deposit

\begin{tabular}{ccccc}
\hline Alternatives & $\mathrm{D}^{+}$ & $\mathrm{D}^{-}$ & $\mathrm{C}_{\mathrm{j}}$ & Rank \\
\hline & $\mathrm{I}$ & $\mathrm{II}$ & $\mathrm{II}$ & $\mathrm{IV}$ \\
\cline { 2 - 5 }$A_{1}$ & 0.73 & 1.37 & 0.65 & 2 \\
$\mathrm{~A}_{2}$ & 0.63 & 1.47 & 0.70 & 1 \\
$\mathrm{~A}_{3}$ & 1.18 & 0.91 & 0.43 & 3 \\
$\mathrm{~A}_{4}$ & 1.85 & 0.25 & 0.12 & 4 \\
\hline
\end{tabular}

The final results show that the ore deposit Južni revir is the best choice for the given conditions. The second choice is Severni revir, the third is Aldinac, while the last is Markov kamen.

In order to define whether the obtained results are reliable and justified, it is desirable to perform a comparison with other proved MCDM methods. In this case, for the verifying of the gained results, the fuzzy extension of the Simple Additive Weighting (SAW) method [48, 49] is applied. The SAW is a well-known and widely used method and therefore it is involved in the testing of the results in this case. In Table 11 the results obtained by applying the fuzzy SAW method are presented.

Table 11 The results obtained by applying the fuzzy SAW method

\begin{tabular}{cccccc}
\hline Alternatives & $\mathrm{I}$ & $\mathrm{m}$ & $\mathrm{r}$ & $\mathrm{S}_{\mathrm{i}}$ & Rank \\
\hline $\mathrm{A}_{1}$ & 0.13 & 0.31 & 0.60 & 0.34 & 2 \\
$\mathrm{~A}_{2}$ & 0.13 & 0.32 & 0.61 & 0.35 & 1 \\
$\mathrm{~A}_{3}$ & 0.12 & 0.29 & 0.53 & 0.31 & 3 \\
$\mathrm{~A}_{1}$ & 0.08 & 0.23 & 0.47 & 0.26 & 4 \\
\hline
\end{tabular}

As can be seen, the ranking order is the same as that one gained from applying the fuzzy TOPSIS method. The alternative $A_{2}$, i.e., the ore deposit called Južni revir is in the first place. The only difference relative to the previous results is that the first and the second alternatives have very close results so it can be concluded that the nuances decided the best choice in this situation.

The presented case clearly outlined the key advantage of the fuzzy TOPSIS method relative to the method used for comparison. Namely, the TOPSIS method gave results that doubtless propound a certain alternative as the best choice. Hence, the decisionmaking process is performed in an easy way and 
without any doubt regarding the performed selection. In the other case, the same results or the results very close to each other could provoke the making of the inappropriate decisions for the present conditions. Besides its reliability, the computation procedure is relatively understandable and simple. By introducing the fuzzy numbers, the optimistic, pessimistic and real expectations are involved in the decision-making procedure making the results more realistic and rational.

\section{Discussion and conclusion}

Selection of an appropriate ore deposit for exploitation among several alternatives must be followed by consideration and evaluation of many conflicting criteria, which leads to a large set of subjective and ambiguous data. The effective evaluation approach is the key of successful decision-making. This paper presents a scientific framework for decision making in the field of mining, i.e., of ore deposit selection, which relies on triangular fuzzy numbers for expressing the linguistic variables that represent the subjective judgments of evaluators and adopts fuzzy multiple criteria decision making approach in order to consolidate the group decision.

In this case, the assessment of the four ore deposits was performed by using fuzzy TOPSIS in the group environment and the results addressed the Južni revir as the most suitable for exploitation. If we look at the input data, we can easily conclude that this alternative meets the all criteria. Some of the criteria are little bit less relative to the other alternatives ( $\%$ of copper or gold), but its location, size and exploitation conditions justifies its first position.

The proposed methodology based on the fuzzy TOPSIS method proves its applicability in the case of ore deposit evaluation and selection. It could be a useful tool for evaluating and ranking of any given set of alternative ore deposits because it offers a more objective, simple and consistent evaluation which is convenient for the preliminary analysis. The main deficiency of the paper reflects thorough the chosen evaluation criteria. The obtained results would be more representative if the additional criteria are involved such as mineralogical composition as well as the ecological and economic aspects of exploitation. But, despite that, the proposed methodology could be a useful aid for the mining engineers and help them to facilitate the decision process in the field of mining exploitation.

\section{Acknowledgment}

The research presented in this paper was done with the financial support of the Ministry of Education, Science and Technological Development of the Republic of Serbia, within the funding of the scientific research work at the University of Belgrade, Technical Faculty in Bor, according to the contract, registration number 451-03-68/2020-14/ 200131.

\section{References}

[1] Herath, G., Prato, T. (2006) Using multi-criteria decision analysis in natural resource management. Ashgate Publishing Limited, Hampshire.

[2] Duckstein, L., Opricovic, S. (1980) Multiobjective optimization in river basin development. Water Resources Research, 16, 14-20.

[3] Belton, V., Stewart, T. J. (2002) Multiple criteria decision analysis, an integrated approach. Kluwer Academic Publishers, Massachusets.

[4] Ballestero, E., Romero, C. (1998) Multiple criteria decision making and its applications to economic problems. Kluwer Academic Publishers, Netherlands.

[5] Korhonen, P., Moskowitz, H., Wallenius, J. (1992) Multiple criteria decision support, a review. European Journal of Operational Research, 63, 361-375.

[6] Hayashi, K. (2000) Multi-criteria analysis for agricultural resource management: a critical survey and future perspectives. European Journal of Operational Research, 122, 486-500.

[7] Mendoza, G. A., Martins, H. (2006) Multi-criteria decision analysis in natural resource management, a critical review of methods and new modeling paradigms. Forest Ecology and Management, 230 (1-3), 1-22.

[8] Hebblewhite B.K. (2007) Management of geotechnical risks in mining projects. School of Mining Engineering, The University of New South Wales, Sydney NSW, Australia.

[9] Alpay, S., Yavuz, M. (2007) A decision support system for underground mining method selection. Lecture Notes in Computer Science, 4570, 334343.

[10] Naghadehi, M. Z., Mikaeli, R., Ataei, M. (2009) The application of fuzzy analytic hierarchy process (FAHP) approach to selection of optimum underground mining method for Jajarm bauxite 
mine, Iran. Expert Systems with Applications, 36(4), 8218-8226.

[11] Balusa, B. C., Gorai, A. K. (2019) Sensitivity analysis of fuzzy-analytic hierarchical process (FAHP) decision-making model in selection of underground metal mining method. Journal of Sustainable Mining, 18(1), 8-17.

[12] Samimi Namin, F., Shahriar, K., Ataee-pour, M., Dehghani, H. (2008) A new model for mining method selection of mineral deposit based on fuzzy decision making. The Journal of the Southern African Institute of Mining and Metallurgy, 108(7), 385-395.

[13] Bogdanovic, D., Nikolic, D., Ilic, I. (2012) Mining method selection by integrated AHP and PROMETHEE method. Anais da Academia Brasileira de Ciências, 84(1), 219-233.

[14] Popović, G., Đorđević, B., Milanović, D. (2019) Multiple criteria approach in the mining method selection. Industrija, 47(4), 47-62.

[15] Azimi, R., Yazdani-Chamzini, A., Majid, M., Zavadskas, E. K., Hossein Basiri, M. (2011) Ranking the strategies of mining sector through AHP and TOPSIS in a SWOT framework. Journal of Business, Economics and Management, 12(4), 670-689.

[16] Kluge, P., Malan, D. F. (2011) The application of the analytical hierarchical process in complex mining engineering design problems. The Journal of The Southern African Institute of Mining and Metallurgy, 111, 847-855.

[17] Stanujkic, D., Magdalinovic, N., Milanovic, D., Magdalinovic, S., Popovic, G. (2014) An efficient and simple multiple criteria model for a grinding circuit selection based on MOORA method. Informatica, 25(1), 73-93.

[18] Stanujkic, D., Zavadskas, E. K., Karabasevic, D., Milanovic, D., Maksimovic, M. (2019) An approach to solving complex decision-making problems based on IVIFNs: A case of comminution circuit design selection. Minerals Engineering, 138, 70-78.

[19] Nouri, R., Afzal, P., Arian, M., Jafari, M., Feizi, F. (2013) Reconnaissance of copper and gold mineralization using Analytical Hierarchy Process (AHP) in the Rudbar 1:100,000 map sheet, Northwest Iran. Journal of Mining and Metallurgy, 49A(1), 9-19.

[20] Jiang J., Yu-wang C., Ying-wu C., Ke-wei Y. (2011) TOPSIS with fuzzy belief structure for group belief multiple criteria decision making. Expert Systems with Applications, 38, 9400-9406

[21] Mahmoodzadeh, S., Shahrabi, J., Pariazar, M., Zaeri, M. S. (2007) Project selection by using fuzzy AHP and TOPSIS technique. International Journal of Human and Social Sciences, 1, 59-66.

[22] Ertugrul, I., Karakasoglu, N. (2009) Performance evaluation of Turkish cement firms with fuzzy analytic hierarchy process and TOPSIS methods. Expert Systems with Applications, 36(1), 702-715.

[23] Ying-Ming, W., Taha M.S. Elhag. (2006) Fuzzy TOPSIS method based on alpha level sets with an application to bridge risk assessment. Expert Systems with Applications, 31, 309-319.

[24] Saremi, M., Mousavi, S. F., Sanayei, A. (2009) TQM consultant selection in SMEs with TOPSIS under fuzzy environment. Expert Systems with Applications, 36, 2742-2749.

[25] Bazzazi, A. A., Osanloo, M., Soltanmohammadi, H. (2008) Loading-haulage equipment selection in open pit mines based on fuzzy-TOPSIS method. Gospodarka Surowcami Mineralnymi, 24(4/3), 87102.

[26] Alavi I., Alinejad-Rokny H. (2011) Comparison of Fuzzy AHP and Fuzzy TOPSIS Methods for Plant Species Selection (Case study: Reclamation Plan of Sungun Copper Mine; Iran). Australian Journal of Basic and Applied Sciences, 5(12), 1104-1113.

[27] Gligoric, Z., Beljic, C., Simeunovic, V. (2010) Shaft location selection at deep multiple orebody deposit by using fuzzy TOPSIS method and network optimization. Expert Systems with Applications, 37(2), 1408-1418.

[28] Kumar, K., Garg, H. (2018) TOPSIS method based on the connection number of set pair analysis under interval-valued intuitionistic fuzzy set environment. Computational and Applied Mathematics, 37(2), 1319-1329.

[29] Kumar, K., Garg, H. (2018) Connection number of set pair analysis based TOPSIS method on intuitionistic fuzzy sets and their application to decision making. Applied Intelligence, 48(8), 21122119.

[30] Liang, D., Xu, Z. (2017) The new extension of TOPSIS method for multiple criteria decision making with hesitant Pythagorean fuzzy sets. Applied Soft Computing, 60, 167-179.

[31] Wang, T. C., Chang, T. H. (2007) Application of TOPSIS in evaluating initial training aircraft under a fuzzy environment. Expert Systems with Applications, 33(4), 870-880. 
[32] Chu, T. C., Lin, Y. C. (2002) Improved extensions of the TOPSIS for group decision-making under fuzzy environment. Journal of Information \& Optimization Sciences, 23(2), 273-286.

[33] Deng, H., Yeh, C. H., Willis, R. J. (2000) Intercompany comparison using modified TOPSIS with objective weights. Computers \& Operations Research, 27, 963-973.

[34] Olson, D. L. (2004) Comparison of weights in TOPSIS models. Mathematical and Computer Modeling, 40(7-8), 721-727.

[35] Jahanshahloo, G.R., Hosseinzadeh Lotfi, F., Izadikhah, M. (2006) Extension of the TOPSIS method for decision-making problems with fuzzy data. Applied Mathematics and Computation, 181(2), 1544-1551.

[36] Zadeh, L. A. (1965) Fuzzy sets. Information and Control, 8(3), 338-353

[37] Chen, C. T. (2000) Extensions to the TOPSIS for group decision-making under fuzzy environment. Fuzzy Sets and Systems, 114(1), 1-9.

[38] Zadeh, L. A. (1975) The concept of linguistic variable and its application to approximate reasoning - I. Information Sciences, 8(3), 199-249.

[39] Zadeh, L. A. (1975) The concept of linguistic variable and its application to approximate reasoning - II. Information Sciences, 8(4), 301-357.

[40] Zadeh, L. A. (1975) The concept of linguistic variable and its application to approximate reasoning - III. Information Sciences, 9(1), 43-80.

[41] Wang, M. J. J., Chang, T. C. (1995) Tool steel materials selection under fuzzy environment. Fuzzy Sets and Systems, 72, 263-270.
[42] Maleki, B., Mozzafari, E., Mahdavipour, M. J. (2016) Optimizing the cut off grade in Sarcheshmeh copper mine using Lane Quartet Model. Journal of Mining and Metallurgy, 52A(1), 27-35.

[43] Zhang, N., Zhou, K., \& Du, X. (2017) Application of fuzzy logic and fuzzy AHP to mineral prospectivity mapping of porphyry and hydrothermal vein copper deposits in the Dananhu-Tousuquan island arc, Xinjiang, NW China. Journal of African Earth Sciences, 128, 84-96.

[44] Panahi, S., Khakzad, A., \& Afzal, P. (2017) Application of stepwise weight assessment ratio analysis (SWARA) for copper prospectivity mapping in the Anarak region, central Iran. Arabian Journal of Geosciences, 10(22), 484.

[45] Group of authors. (2011) Potentials of economic development of municipality of Majdanpek. Faculty of Management Zajecar, Zajecar (In Serbian).

[46] Group of authors. (2010) Potentials of economic development of municipality of Knjazevac. Faculty of Management Zajecar, Zajecar (In Serbian).

[47] Group of authors. (2010) Potentials of economic development of municipality of Boljevac. Faculty of Management Zajecar, Zajecar (In Serbian).

[48] Churchman, C. W., Ackoff, R. L. (1954) An approximate measure of value. Journal of the Operations Research Society of America, 2(2), 172187.

[49] Fishburn, P. C. (1967) Additive utilities with incomplete product set: applications to priorities and assignments. Operations Research, 15(3), 537-542. 


\section{MODEL ZA ODABIR RUDNOG LEŽIŠTA ZASNOVAN NA FAZI TOPSIS METODI}

\section{G. Popović1 , D. Stanujkić², D. Karabašević1, Z. Štirbanović}

1 University Business Academy in Novi Sad, Faculty of Applied Management, Belgrade, Serbia

2University in Belgrade, Technical Faculty, Bor, Serbia

(Primljen: 8. maj 2020.; Prihvaćen: 17. jun 2020.)

\section{Izvod}

Donosioci odluka se često susreću sa nepreciznim i nejasnim podacima. Pod datim uslovima, upotreba ekstenzije metode Višekriterijumskog Odlučivanja (VKO) je pogodnija od upotrebe ostalih klasičnih metoda za donošenje odluka. U ovom radu je predstavljen model za evaluaciju koji se zasniva na TOPSIS metodi, a koji je namenjen izboru odgovarajućeg rudnog ležišta u fazi okruženju. Primenljivost predloženog modela je predstavljena na studiji slučaja koja uključuje četiri rudna ležišta, sedam evaluacionih kriterijuma i tri donosioca odluka.

Ključne reči: Odabir rudnog ležišta; Fazi TOPSIS metoda; VKO. 